J. Japan. Soc. Hort. Sci. 57(2) : 184-190. 1988.

\title{
Influence of the Disorder Bitter Pit on Microsomal Vanadate-Sensitive ATPase Activity from Apple Fruit
}

\author{
Masashi Fuкumoto ${ }^{1}$, Koji Аова ${ }^{1}$, Hiroto YoshioкA ${ }^{1}$ \\ and Koushirou NAGAI ${ }^{2}$ \\ ${ }^{1}$ Morioka Branch, Fruit Tree Research Station, \\ Shimokuriyagawa, Morioka 020-01 \\ ${ }^{2}$ Fruit Tree Research Station, Yatabe, Ibaraki 305
}

\begin{abstract}
Summary
"Fuji" apple trees on Malus prunifolia rootstock showed a higher incidence of bitter pit (a physiological disorder of apple fruit) when ammonium salt rather than nitrate was supplied in the nutrient solution. The number of spots induced by bitter pit was intimately associated with a decrease in the calcium content of the fruits.

Proton transport and $\left(\mathrm{K}^{+}+\mathrm{Mg}^{2+}\right)$-A TPase activity were observed in the microsomal fraction of the fruit flesh of apple. Sodium vanadate at $0.1 \mathrm{mM}$ decreased $\left(\mathrm{K}^{+}+\right.$ $\mathrm{Mg}^{2+}$ )-ATPase activity to $8 \%$ of the control and inhibited the proton transport. Neither the proton transport nor the $\left(\mathrm{K}^{+}+\mathrm{Mg}^{2+}\right)$-A TPase activity was inhibited by nitrate at $50 \mathrm{mM}$. On a continuous sucrose density gradient the distribution of the vanadate-sensitive ATPase activity was different from those of NADPH-cytochrome $\mathrm{c}$ reductase and cytochrome c oxidase activities. In apples seriously affected with bitter pit, proton transport and the vanadate-sensitive ATPase were reduced respectively to $37 \%$ and $55 \%$ of the levels in healthy fruit, while fruits slightly affected with bitter pit showed a higher activity of the vanadate-sensitive ATPase and a similar proton transport activity to that in healthy fruit.

The relationship between bitter pit disorder and the changes in the microsomal proton transport and vanadate-sensitive ATPase activities is discussed.
\end{abstract}

\section{Introduction}

Bitter pit, a physiological disorder of apple, is now recognized as a calcium-deficient disorder, although an excess of nitrogen, potassium or magnesium increases its incidence $(10,11,13,14)$. We have also shown an intimate relationship between bitter pit and calcium deficiency, and the development of bitter pit-like spots following infiltration with calmodulin antagonists(5). Marinos(8) observed by electromicroscopy of barley tissues that calcium deficiency induced the destruction of tonoplasts and plasmalemma. Several researchers showed that the occurrence of bitter pit increased the $\mathrm{K}^{+}$efflux

Received for publication May 13, 1987.

This paper is contribution No. C-122. from the tissues $(6,12,17)$. Matsumoto and Yamaya(9) reported that the $\mathrm{K}^{+}$-stimulated ATPase activity for putative plasma membranes from cucumber roots and the $\mathrm{K}^{+}$uptake in the intact roots were repressed by $\mathrm{Ca}^{2+}$ starvation.

These findings prompted us to investigate whether changes in the proton-translocating ATPase are related to the occurrence of bitter pit.

In the present paper the effect of calcium on the occurrence of bitter pit, and the changes in microsomal proton transport and vanadate-sensitive ATPase activity of apple fruit with its occurrence are described.

\section{Materials and methods}

Plant materials. Eight-year old "Fuji" 
apple trees on Malus prunifolia rootstock were grown in water culture medium using $4 \mathrm{mM}$ ammonium- or nitrate-nitrogen as described previously(5). The apple fruits with or without bitter pit were taken at harvest and stored at $0^{\circ} \mathrm{C}$ until used. The incidence of bitter pit was determined just before harvest. All experiments described here were done by using mature fruits which were harvested from the water culture field at Morioka Branch, Fruit Tree Research Station.

Preparation of microsomal fraction. Peels, stems and cores were removed from mature apple fruits and the fruit fiesh was used in the present experiment. For determining the effect of bitter pit disorder on the microsomal proton transport and ATPase activities, the flesh was cut at the equator and the flesh near the calyx end removed and the healthy flesh near the pitted area was used. The fruit flesh was sliced and homogenized in 2 volume sof $0.25 \mathrm{M}$ sucrose, $4 \mathrm{mM}$ DTT, $2 \mathrm{mM}$ EDTA, $0.2 \%$ (w/v) bovine serum albumin, $5 \%(\mathrm{w} / \mathrm{v})$ polyvinylpolypyrrolidone and $0.2 \mathrm{M}$ Tris- $\mathrm{HCl}$ ( $\mathrm{pH} 7.5)$ with an ice-cold mortar and pestle. After filtering through four layers of gauze, the $6,000 \times \mathrm{g}$ for $10 \mathrm{~min}$, and $50,000 \times \mathrm{g}$ for $30 \mathrm{~min}$ fraction was prepared by differential centrifugation. The microsomal pellets were resuspended in a small amount of $0.25 \mathrm{M}$ sucrose and $2 \mathrm{mM}$ Tris-2 $\mathrm{mM}$ MES ( $\mathrm{pH} 7.0$ ) and used for determining the proton transport and the $\left(\mathrm{K}^{+}+\mathrm{Mg}^{2+}\right)$-ATPase activity. The 6,000 $\times$ $\mathrm{g}$ for $10 \mathrm{~min}$ and $80,000 \times \mathrm{g}$ for $30 \mathrm{~min}$ fraction, instead of the $50,000 \mathrm{~g}$ pellet, was layered onto a continuous sucrose gradient and centrifuged for $2 \mathrm{hr}$ at $80,000 \times \mathrm{g}$ in a Hitachi RPS 25-2 rotor.

ATPase assays. ATPase activity was measured at $30^{\circ} \mathrm{C}$ for $15 \mathrm{~min}$. The standard assay mixture $(1 \mathrm{ml})$ contained $75 \mathrm{mM}$ TrisMES (pH 7.2), $3 \mathrm{mM} \mathrm{MgCl}, 3 \mathrm{mM}$ ATP$\mathrm{Na}_{2}$ (neutralized with Tris), $50 \mathrm{mM} \mathrm{KCl,} 1$ $\mathrm{mM} \mathrm{NaN}, \quad 0.1 \mathrm{mM}$ ammonium molybdate and a proper amount of the membrane vesicles. Phosphate was determined by the Fiske-Subbarow method modified by Tashima (16). The $\left(\mathrm{K}^{+}+\mathrm{Mg}^{2+}\right)$-ATPase activity was corrected for that of a basal ATPase lacking
$\mathrm{K}^{+}$and $\mathrm{Mg}^{2+}$. Vanadate-sensitive ATPase activity is defined as the difference between the activities in the absence and the presence of $0.1 \mathrm{mM}$ sodium vanadate.

Fluorescence assays. Formation of interior acid $\mathrm{pH}$ gradients was monitored as the quenching of fluorescence of quinacrine as previously reported by Bennett et al(1). The standard assay mixture $(2.5 \mathrm{ml})$ was composed of $0.25 \mathrm{M}$ sucrose, $3 \mathrm{mM} \mathrm{MgCl}_{2}$, $50 \mathrm{mM} \mathrm{KCl}, 1 \mathrm{mM} \mathrm{NaN}, 3 \mathrm{mM}$ ATP- $\mathrm{Na}_{2}$ (neutralized with Tris), $0.01 \mathrm{mM}$ quinacrine, $60 \mathrm{mM}$ Tris-60 mM MES (pH 7.2) and the microsomal fraction $(60-200 \mu \mathrm{g}$ membrane protein). Fluorescence was measured at $28^{\circ} \mathrm{C}$ with a Jasco FP-770 spectrofluorimeter at excitation and emission wavelengths of 423 $\mathrm{nm}$ and $500 \mathrm{~nm}$, respectively. The reaction medium was continuously stirred with a magnetic bar.

Chemical estimations. The fruit flesh was freeze-dried, milled and used for chemical estimations. The contents of nitrogen, potassium, calcium and magnesium were determined as described earlier(5).

$\mathrm{NADPH}$-cytochrome $\mathrm{C}$ reductase and cytochrome $\mathrm{C}$ oxidase were assayed spectrophotometrically(7). Protein content was measured by a modified Lowry method(2).

\section{Results and Discussion}

Induction of bitter pit by ammonium supply. We previously reported that ammonium supply increased the incidence of bitter pit in apple fruit(5). In this experiment $53.3 \%$ of apple fruits were affected with bitter pit at harvest time in the ammonium treatment, while the incidence was only $1.9 \%$ in fruit supplied with nitrate (Table 1). The affected fruit had a lower content of calcium and a higher content of nitrogen than the unaffected fruit (Table 2). Interestingly, the symptom of bitter pit was remarkably influenced by the calcium content of the fruit flesh (Table 3). The more seriously the apple fruit was damaged by bitter pit, the lower the calcium content of the fruit flesh (Table 3).

Three types of proton-translocating ATPase have so far been reported in higher 
Table 1. Induction of bitter pit by ammonium supply in water culture medium.

\begin{tabular}{lccc} 
Treatment & $\begin{array}{c}\text { Incidence of } \\
\text { bitter pit } \\
(\%)\end{array}$ & $\begin{array}{c}\text { Yeld } \\
(\mathrm{kg})\end{array}$ & $\begin{array}{c}\text { Mean fruit } \\
\text { weight } \\
(\mathrm{g})\end{array}$ \\
\hline Nitrate $(4 \mathrm{mM})$ & $1.9 \pm 2.0^{z}$ & $33.5 \pm 9.1$ & $237 \pm 14$ \\
Ammonium(4mM) & $53.3 \pm 7.7$ & $20.8 \pm 3.0$ & $205 \pm 7$
\end{tabular}

$z$ The results represent the mean \pm SD from 3 replicate trees.

Table 2. Effect of bitter pit disorder on the contents of nitrogen, potassium, calcium and magnesium in the flesh of mature apple fruit.

\begin{tabular}{lccll}
\hline \hline & Nitrogen & Potassium & Calcium Magnesium \\
\hline & \multicolumn{4}{c}{ (\% dry weight basis) } \\
Healthy fruit & 0.141 & 0.413 & 0.0182 & 0.0151 \\
& $\pm 0.020^{z}$ & \pm 0.038 & \pm 0.0019 & \pm 0.0027 \\
Affected fruit & 0.260 & 0.363 & 0.0097 & 0.0140 \\
& \pm 0.057 & \pm 0.042 & \pm 0.0004 & \pm 0.0015
\end{tabular}

$z$ The results represent the mean \pm SD of 3 replications of 3 apple fruits each.

Table 3. Effect of calcium content of the fruit flesh of apple on the symptom of bitter pit.

\begin{tabular}{cc}
\hline \hline Number of spots & $\begin{array}{c}\text { Calcium Content } \\
\text { (ppm, dry weight basis) }\end{array}$ \\
\hline Healthy Fruity & $138.0^{\mathrm{a}}$ \\
$1 \sim 3$ & $98.3^{\mathrm{b}}$ \\
$4 \sim 10$ & $75.9^{\mathrm{c}}$ \\
$>20$ & $61.0^{\mathrm{d}}$ \\
\hline
\end{tabular}

z Mean separation within columns by Duncan's multiple range test, $5 \%$ level. plants, that is, plasma membrane-, tonoplast- and golgi membrane-type ATPases(3, 15). Vanadate and nitrate are useful tools to discriminate between them. The plasma membrane-type ATPase activity is vanadatesensitive and nitrate-insensitive, but the tonoplast-type one is vanadate-insensitive and nitrate-sensitive(15). The golgi membranetype one is thought to be vanadate-insensitive and less sensitive to nitrate (3). As

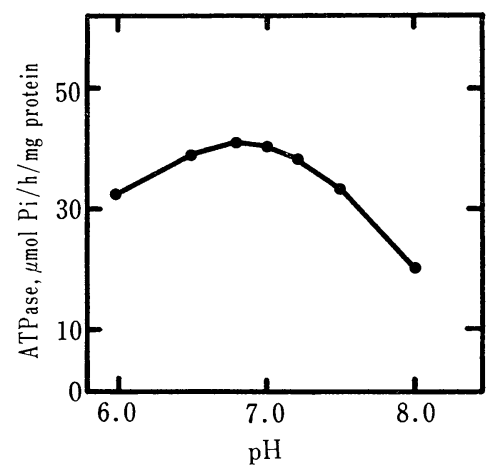

Fig. 1. Effect of $\mathrm{pH}$ on $\left(\mathrm{K}^{+}+\mathrm{Mg}^{2+}\right)$-ATPase activity by microsomal fraction from apple fruit. The results indicate means of 2 replications.

Each of the assay medium contained $0.5 \mathrm{mM}$ EGTA, $75 \mathrm{mM}$ Tris-MES (pH 7.2), $3 \mathrm{mM} \mathrm{MgCl}_{2}, 3 \mathrm{mM}$ ATP$\mathrm{Na}_{2}, \quad 50 \mathrm{mM} \mathrm{KCl}, \quad 1 \mathrm{mM} \mathrm{NaN}, \quad 0.1 \mathrm{mM}$ ammoninm molybdate and a proper amount of the membrane vesicles.

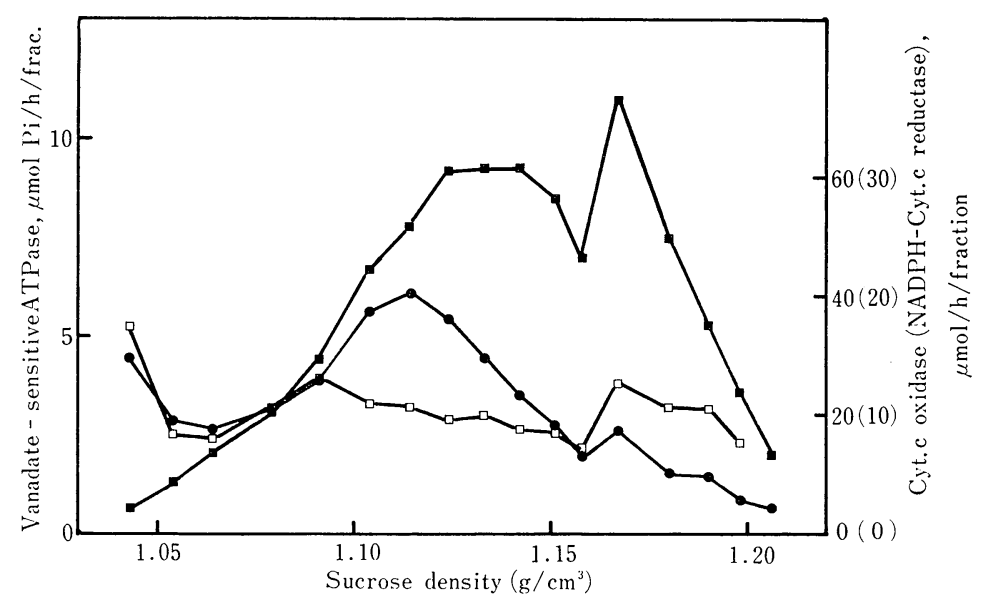

Fig. 2. Distribution of vanadate-sensitve ATPase, cytochrome c oxidase and NADPHcytochrome $\mathrm{c}$ reductase activities on a continuous sucrose gradient of the microsome fraction from apple fruit. Vanadate-sensitive ATPase (O), cytochrome c oxidase (ש), NADPH-cytochrome c reductase $(\square)$. 
Table 4. Effect of chemicals on the microsomal ( $\mathrm{K}^{+}$ $\left.+\mathrm{Mg}^{2+}\right)$-ATPase activity from apple fruit.

\begin{tabular}{lcr}
\multicolumn{1}{c}{ Treatment } & Activity (nmol/g FW/min) & $(\%)$ \\
\hline Control & 16.3 & 100 \\
$+\mathrm{Na}_{3} \mathrm{VO}_{4}, 0.1 \mathrm{mM}$ & 1.3 & 8 \\
$+\mathrm{Gramicidine}, 2 \mu \mathrm{M}$ & 19.9 & 122 \\
$+\mathrm{KNO}_{3}, \quad 50 \mathrm{mM}^{2}$ & 14.9 & 91 \\
\hline
\end{tabular}

The results represent means of 2 replications.

$z$ Potassium nitrate was added instead of potassium chloride.

Table 4 shows, microsomal $\left(\mathrm{K}^{+}+\mathrm{Mg}^{2+}\right)-$ A TPase from apple fruit was decreased to $8 \%$ of the control by adding $0.1 \mathrm{mM}$ sodium vanadate, but little affected by nitrate at 50 $\mathrm{mM}$. The addition of gramicidin $\mathrm{D}$ at $2 \times$ $10^{-3} \mathrm{mM}$ increased the ATPase activity to $122 \%$ of the control, indicating that the microsomal fraction contained tightly-sealed vesicles(1). The optimum $\mathrm{pH}$ was around 7. 0 (Fig. 1).

The microsomal fraction from apple fruit was fractionated by continuous sucrose density centrifugation (Fig. 2). The major peak of the vanadate-sensitive ATPase activity was at $1.11 \mathrm{~g} / \mathrm{cm}^{3}$, while the major peaks of the cytochrome c oxidase activity, a marker for mitochondria, and the NADPH-cytochrome c reductase activity, a marker for endoplasmic reticulum, were at $1.14 \mathrm{~g} / \mathrm{cm}^{3}$ and $1.04 \mathrm{~g} / \mathrm{cm}^{3}$, respectively.

These findings indicate that the vanadatesensitive ATPase described here has similar characteristics to the plasma membrane-type proton-translocating ATPase, except that the distribution of this ATPase activity showed a lower density peak than that $(1.13 \sim 1.17$ $\mathrm{g} / \mathrm{cm}^{3}$ ) of the previously characterized plasma membrane-type ATPase activity(15). We observed that the peak of the vanadate-sensitive ATPase activity was shifted to 1.19 $\mathrm{g} / \mathrm{cm}^{3}$ by homogenizing in a buffer solution containing $4 \mathrm{mM} \mathrm{MgSO}_{4}$ followed by a continuous sucrose density centrifugation with $4 \mathrm{mM} \quad \mathrm{MgSO}_{4}$ (data not shown). Apple fruit has quite a low magnesium content as compared to any other part of the apple tree (4). The lower density of this ATPase activity might be due to its low magnesium content.
Table 5. Distribution of the vanadate-sensitive ATPase activity in the homogenate fractionated by differential centrifugation.

\begin{tabular}{clcr} 
Fruit & & \multicolumn{2}{c}{$\begin{array}{c}\text { Vanadate-sensitive ATPase } \\
\text { (nmol/g FW/min) }\end{array}$} \\
\cline { 2 - 4 } & $\begin{array}{l}6,000 \times \\
\text { g pellet }\end{array}$ & $\begin{array}{c}6,000- \\
50,000 \times \mathrm{g}\end{array}$ & Supernatant \\
\hline Exp. 1 & & & \\
Healthy & $7.1(26 \%)^{\mathrm{y}}$ & $12.7(47 \%)$ & $7.4(27 \%)$ \\
$\quad \begin{array}{l}\text { Affected } \\
\text { Exp. 2 }\end{array}$ & $7.0(30 \%)$ & $10.1(44 \%)$ & $5.9(26 \%)$ \\
Healthy & $6.7(24 \%)$ & $13.1(46 \%)$ & $8.4(30 \%)$ \\
Affected & $7.4(29 \%)$ & $11.3(45 \%)$ & $6.4(25 \%)$ \\
\hline
\end{tabular}

The affected fruits had $7-10$ spots.

${ }^{z}$ used after being stored at $0^{\circ} \mathrm{C}$ for about 3 months.

$\mathrm{y}$ indicate the $\%$ basis of the total activity in each fruit.

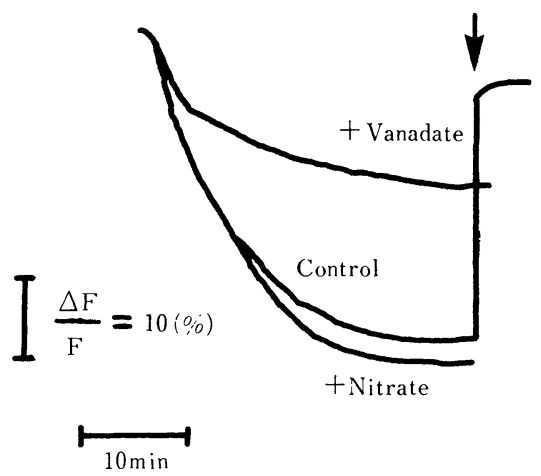

Fig. 3. Proton transport by microsomal fraction from apple fruit. Vanadate and nitrate were added at $0.1 \mathrm{mM}$ and $50 \mathrm{mM}$, respectively. The arrow indicates the addition of gramicidine $\mathrm{D}$ at $2 \mu \mathrm{M}$.

Microsomal proton transport. The microsomal fraction from apple fruit catalysed ATP-dependent quenching of quinacrine fluorescence (Fig. 3), which indicates the formation of an acid interior $\mathrm{pH}$ gradient as previously reported in red beet(1). The protontransporting activity reached a steady state after about $15 \mathrm{~min}$. Both microsomal proton transport and the microsomal ATPase were inhibited by sodium vanadate but not by nitrate. This proton transport seems to be controlled through the vanadate-sensitive ATPase activity.

Effect of bitter pit disorder on the activities of microsomal proton transport and vanadate-sensitive ATPase. Table 5 shows the distribution of vanadate-sensitive ATPase 


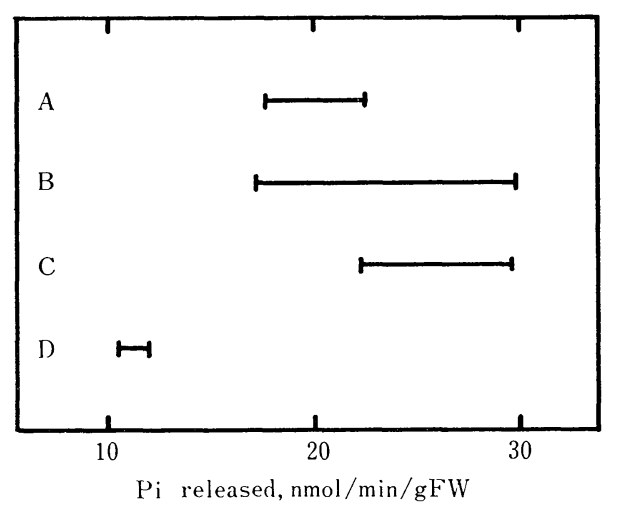

Fig. 4. Effect of bitter pit disorder on micromal vanadate-sensitive ATPase activity from apple fruit which was stored at $0^{\circ} \mathrm{C}$ for $2-3$ weeks.

(A) : Healthy fruit (Control), the nitrate treatment; (B) : unaffected fruit, the ammonium treatment; (C): affected fruit, less than 5 spost ; (D) : affected fruit, more than 20 spots. Each bar expresses the mean \pm SD $(\mathrm{n}=5$ except for $\mathrm{D}, \mathrm{n}=3$ ).

among $6,000 \times$ g precipitate, $6,000 \sim 50,000 \times \mathrm{g}$ (microsomal fraction) and the supernatant from healthy and affected fruits. The affected fruit used in this experiment had 7 to 10 spots. The microsomal fractions of the healthy and the affected fruits recovered 46 $47 \%$ and $44 \sim 45 \%$, respectively, of the total vanadate-sensitive ATPase activity, demonstrating that the recovery of this activity may be little changed whether apple fruit is affected with bitter pit or not. In the presence of gramicidin $\mathrm{D}$ at $2 \times 10^{-3} \mathrm{mM}$ vanadate-sensitive ATPase activity from the affected fruit was increased to $113 \%$ of the control (data not shown). This suggests that the ATPase might reside in sealed membrane vesicles, although the membranes from the affected fruit might be less able to form tightly-sealed vesicles than those from the healthy fruit.

Apple fruits affected with bitter pit were divided into two groups. One is fruits seriously damaged by bitter pit which have more than 20 large deep spots. The other is slightly affected fruits which have less than 5 small spots. When apple fruit was seriously affected, the vanadate-sensitive ATPase activity was remarkably lowered to $55 \%$ of the control (Fig. 4). Fruit slightly affected, however, had a higher activity of this

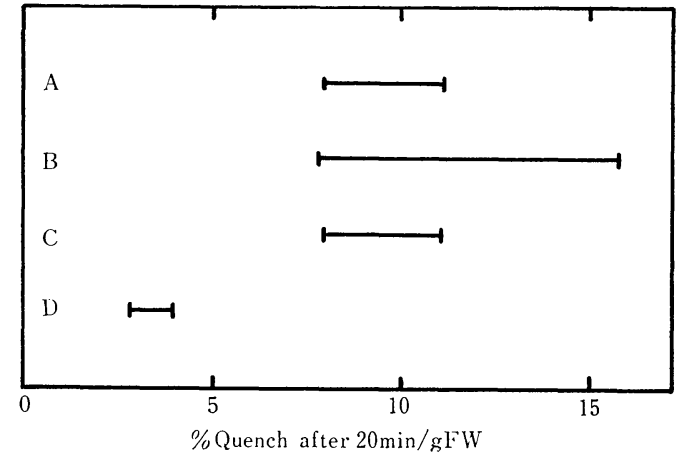

Fig. 5. Effect of bitter pit disorder on microsomal proton transport from apple fruit which was stored at $0^{\circ} \mathrm{C}$ for $2-3$ weeks.

(A), (B), (C), (D) and the bars are the same as shown in Fig.3.

ATPase than the control. Figure 5 shows the effect of bitter pit on quenching after 20 min of quinacrine fluorescence, which expresses the ability of the microsomal vesicles to form a $\mathrm{pH}$ gradient, with the inside acidic. Fruit seriously affected with bitter pit showed a lower capability for this formation, while slightly affected fruit had a very similar capability to the control. As Figures 4 and 5 show, the unaffected fruits obtained from trees treated with ammonium-nitrogen had slightly higher activities of the proton transport and the vanadate-sensitive ATPase than the healthy fruits.

The unaffected fruits tend to contain a higher nitrogen and a lower calcium content than the healthy fruit(5). In the present study the effect of calcium on the changes of proton-translocating ATPase activity with the occurrence of bitter pit is not separated from that of nitrogen. At the first stage of decrease in calcium content and/or increase in nitrogen content of apple fruits, the proton-translocating ATPase activity described here seems to be stimulated. Then this ATPase activity may be drastically decreased. A proton pump catalysed by a $\left(\mathrm{K}^{+}+\mathrm{Mg}^{2+}\right)-$ ATPase associated with the cell membranes is now considered to be the primary transport process in higher plants(15). The occurrence of bitter pit was followed by the increase in $\mathrm{K}^{+}$efflux from apple tissues $(6,12,17)$, suggesting that the affected fruit may have 
"leaky membranes". Thus the cell membranes of the affected fruit would have a higher energy demand to keep a normal transport system in the cells. That might be a reason for the temporary rise in the vanadate-sensitive ATPase activity followed by the development of bitter pit. Furthermore, it is tempting to think that the metabolic function of cell membranes in the pitted area had been disturbed before bitter pit occurred.

Unfortunately, we failed to find the tonoplast-type ATPase activity from apple fruit in spite of the fact that more than $80 \%$ of the cell volume is occupied by vacuoles(18). It will be necessary to consider the transport system in the apple tonoplast to elucidate the role of vacuoles in this disorder.

\section{Acknowledgments}

We wish to thank Drs. N. K. Given and N. H. Battey, Institute of Horticultural Research-East Malling, U. K. for critical reading of the manuscript. We are also grateful to $\mathrm{Mr}$ K. Fujimoto and Mrs T. Itoh for their technical assistance.

\section{Literature cited}

1. Bennett, A. B., S. D. O'Neill and R. M. SpanSwICK. 1984. $\mathrm{H}^{+}$-ATPase activity from storage tissue of Beta vulgaris. 1. Identification and characterization of an anion-sensitive $\mathrm{H}^{+}$-A TPase. Plant Physiol. $74: 538-544$.

2. Bensadoun, A. and D. Weinstein. 1976. Assay of proteins in the presence of interfering materials. Anal. Biochem. $70: 241-$ 250.

3. Chanson, A. and L. TAiz. 1985. Evidence for an ATP-dependent proton pump on the golgi corn coleoptiles. Plant Physiol. 78 : 232-240.

4. Funumoto, M. and K. Nagai. 1981. The intake of ammonium and nitrate by apple trees. Bull. Fruit Tree Res. Stn. C-8:57-65 (in Japanese with English summary).

5. Fukumoto, M. and K. NAGAi. 1983. Possible roles of calcium and ammonium in the development of bitter pit in apple. Physiol. Plant. $59: 171 \sim 176$.

6. FukUmoto, M., K. NAGAI, H. Yoshioka and K. AOBA. 1987. Mechanism of the development of a calcium-related disorder (bitter pit) in apple. JARQ $20: 24-28$.
7. LeONARd, R. T., D. Hanson and T. K. Hodges. 1973. Membrane-bound adenosine triphosphate activities of oat roots. Plant Physiol. $51: 749-754$.

8. MARINOS, N. G. 1962. Studies on submicroscopic aspects on mineral deficiencies. 1. Calcium deficiency in the shoot apex of barley. Amer. J. Bot. 49: 834-841.

9. Matsumoto, $\mathrm{H}$. and T. Yamaya. 1984. Repression of the $\mathrm{K}^{+}$uptake and cation-stimulated ATPase activity associated with the plasma membrane-enriched fraction of cucumber roots due to $\mathrm{Ca}^{2+}$ starvation. Plant Cell Physiol. $25: 1501-1511$.

10. MORI, H. and T. YAMAZAKI. 1958. Studies on the nitrogen nutrition of apple trees in water culture. Bull. Tohoku Agr. Exp. Stn. $13: 80-92$ (in Japanesed with English summary).

11. MORI, H. and T. YAMAZAKI. 1960. Studies on the potassium nutrition of apple trees. 1 . Response of apple trees to different potassium supply in nutrient solution of water culture. Bull. Tohoku Agr. Exp. Stn. 18:44-56 (in Japanese with English summary).

12. Rousseau, G. G., F. J. HaAsbroek and C. J. VISSER. 1972. Bitter pit in apples: The effect of calcium on permeability changes in apple fruit tissue. Agroplantae 4:73-80.

13. Sharples, R. O., M. S. REID and N. A. TURNER. 1979. The effect of postharvest mineral element and lecithin treatments on the storage disorders of apples. J. Hortic. Sci. $54: 299-304$.

14. SHEAR, C. B. 1975. Calcium-related disorders of fruits and vegetables. Hortscience 10 : $361-365$.

15. SzE, H. 1984. $\mathrm{H}^{+}$-transloxating A TPases of the plasma membrane and tonoplast of plant cells. Physiol. Plant. 61:683-691.

16. TASHIMA, Y. 1975. Removal of protein interference in the Fiske-Subbarow method by sodium dedecyl sulfate. Anal. Biochem. 69 : 410-414.

17. Van GooR, B. J. 1971. The effect of frequent spraying with calcium nitrate solutions on the mineral composition and the occurrence of bitter pit of the apple Cox's O4ange Pip* pin. J. Hortic. Sci. 46:347-364.

18. YAMAKI, S. 1984. Isolation of vacuoles from immature apple fruit flesh and compartmentation of sugars, organic acids, phenolic compounds and amino acids. Plant Cell Physiol. 25 : 151-166. 
リンゴ果実のバナデート感受性 ATPase 活性に 及ぼすビターピット発生の影響

福元将志 ${ }^{1} \cdot$ 青葉幸二 ${ }^{1} \cdot$ 吉岡博人 ${ }^{1} \cdot$ 長井晃四郎 ${ }^{2}$

農林水産省果樹試眙場盛岡支場 $020-01$ 盛岡市下倣川

2 㖘林水産省果樹試験場 305 淡城県谷田部町

\begin{abstract}
摘 要
リンゴ樹を水耕栽培することによって人為的にビター ピットを発生させた(5). ‘ふじ’のビターピット発生程 度は, 果肉中のカルシウム濃度の減少と密接に関係して いた。

リンゴ果実のミクロゾーム画分にはバナジン酸ナトリ ウムで阻害され，硝酸カリウムで阻害されない $\left(\mathrm{K}^{+}+\right.$ $\mathrm{Mg}^{2+}$ )-ATPase が存在した. また。蛍光物質であるキ ナクリンを用いてプロトンの輸送活性を調べたところ,

たプロトン輸送活性が存在した、卯ち、リンゴ果实には 原形質膜に由来する $\mathrm{H}^{+}$-ATPase が存在すると考えら れた。

ビターピット発生の重症果では, バナデート感受性 ATPase 並びにプロトン輸送活性の著しい低下が珰めら れた・このことから、ビターピットの発生する果実の原 形質膜では，正常な物質輸送を低下させるような変化を 生じていることが推察された.
\end{abstract} 本ミクロゾーム画分には ATPase と同様の性質を持っ 